\title{
REVIEW
}

\section{Melatonin as a free radical scavenger in the ovarian follicle}

\author{
Hiroshi Tamura $^{1)}$, Akihisa Takasaki ${ }^{2}$, Toshiaki Taketani ${ }^{1)}$, Manabu Tanabe ${ }^{1)}$, Fumie Kizuka ${ }^{1)}$, Lifa Lee ${ }^{1)}$, \\ Isao Tamura ${ }^{1)}$, Ryo Maekawa ${ }^{1)}$, Hiromi Asada ${ }^{1)}$, Yoshiaki Yamagata ${ }^{1)}$ and Norihiro Sugino ${ }^{1)}$ \\ 1) Department of Obstetrics and Gynecology, Yamaguchi University Graduate School of Medicine, Ube 755-8505, Japan \\ 2) Department of Obstetrics and Gynecology, Saiseikai Shimonoseki General Hospital, Shimonoseki 759-6603, Japan
}

\begin{abstract}
This review summarizes new findings related to beneficial effects of melatonin ( $\mathrm{N}$-acetyl-5-methoxytryptamine) on reproductive physiology. Recently many researchers have begun to study the local role of melatonin as an antioxidant. We focused on intra-follicular role of melatonin in the ovary. Melatonin, secreted by the pineal gland, is taken up into the follicular fluid from the blood. Reactive oxygen species (ROS) are produced within the follicles, during the ovulatory process. Melatonin reduces oxidative stress as an antioxidant, and contribute to oocyte maturation, embryo development and luteinization of granulosa cells. Our clinical study demonstrated that melatonin treatment for infertile women increases intra-follicular melatonin concentrations, reduces intra-follicular oxidative damage, and elevates fertilization and pregnancy rates. Melatonin treatment also improves progesterone production by corpus luteum in infertile women with luteal phase defect. Melatonin treatment could become a new cure for improving oocyte quality and luteal function in infertile women.
\end{abstract}

Key words: Melatonin, Ovarian follicle, Reactive oxygen species, Oocyte, Granulosa cell

MELATONIN (N-acetyl-5-methoxytryptamine) is secreted during the dark hours at night by pineal gland, and it regulates a variety of important central and peripheral actions related to circadian rhythms and reproduction. It has been believed that melatonin regulates ovarian function by the regulation of gonadotropin release in the hypothalamus-pituitary gland axis via its specific receptors. However, the discovery of melatonin as a direct free radical scavenger has greatly broadened the understanding of melatonin's mechanisms which benefit reproductive physiology. Reactive oxygen species (ROS), which are locally produced during the ovulatory process, seem to have an essential role on follicle rupture. However, excess ROS can also be responsible for oxidative stress; they can damage oocytes and granulosa cells within the follicle. We focused on the direct role of melatonin on oocyte maturation and luteinization of granulosa cells as an anti-oxidant to reduce oxidative stress induced by ROS. This review also discusses the first application of melatonin to the clinical

Submitted Jul. 18, 2012; Accepted Oct. 19, 2012 as EJ12-0263

Released online in J-STAGE as advance publication Nov. 22, 2012

Correspondence to: Hiroshi Tamura, M.D., Ph.D., Department of Obstetrics and Gynecology, Yamaguchi University Graduate School of Medicine, Minamikogushi 1-1-1, Ube 755-8505, Japan. E-mail: hitamura@yamaguchi-u.ac.jp treatment of infertile women with poor oocyte quality or luteal phase defect.

\section{Synthesis of melatonin}

Melatonin (N-acetyl-5-methoxytryptamine), the hormone of the pineal gland, has a circadian rhythm which is generated by the circadian pacemaker situated in the suprachiasmatic nucleus ( $\mathrm{SCN})$ of the hypothalamus, and synchronized to 24 hours primarily by the light-dark cycle acting via the SCN $[1,2]$. During the day, serum melatonin concentrations are low, and significantly increase at night. The synthesis of melatonin is strictly controlled by lighting conditions. Photosensory information arrives at the pineal gland via the polyneuronal pathway that begins in the retina and involves the retinohypothalamic tract, $\mathrm{SCN}$, paraventricular nuclei, intermediolateral cell column of the spinal cord and the superior cervical ganglia [3, 4]. Noradrenalin plays the crucial role in the control of melatonin synthesis [5]. It is released from postganglionic sympathetic nerve fibers that end in the pineal gland, and binds to pinealocyte $\alpha$-adrenergic receptors, activates adenylate cyclase, and increases cAMP levels leading to the stimulation of activity of arylalkulamine $\mathrm{N}$-acetyltransferase (AA-NAT), the key enzyme in 
melatonin synthesis $[6,7]$. The biosynthesis of melatonin is initiated by the uptake of the amino acid L- tryptophan from blood circulation into the gland. Within the pinealocyte, it is catalyzed to 5-hydroxytryptophan which is then decarboxylated to serotonin. The next step, $\mathrm{N}$-acetylation of serotonin to $\mathrm{N}$-acetylserotonin is completed by AA-NAT. The final step in the pathway is the $\mathrm{O}$-methylation of $\mathrm{N}$-acetylserotonin to melatonin by hydroxyindole O-methyltransferase (HIOMT) $[8,9]$.

Once synthesized, melatonin is not stored in pineal cells but is quickly released into the bloodstream and then into other body fluids, such as bile [10], cerebrospinal fluid [11], saliva [12], semen [13], amniotic fluid [14] and ovarian follicular fluid [15]. It has been reported that melatonin has many functions in organisms, i.e., helping to synchronize circadian rhythms $[16,17]$, sleep promotion $[18,19]$, immune stimulation $[20,21]$, blood pressure regulation $[22,23]$, seasonal reproductive regulation [24-26], oncostatic function [27-29], and antidepressive function [30, 31].

Some of the various physiological actions of melatonin are mediated by two G-protein-coupled MT1 and MT2 receptors widely distributed throughout the body. The activation of these receptors reduces forskolinstimulated cAMP formation, protein kinase A activity and phosphorylation of cAMP-responsive element binding, even if the receptors can also interact with other intracellular signaling pathways, including the phosphorylation of mitogen-activated protein kinase kinases 1 and 2 (MEK1 and MEK2), extracellular signal-regulated kinases 1 and 2 (ERK1 and ERK2) and protein kinase C [32]. Depending on the tissue, organ and species, melatonin activates different second messenger cascades by interacting with the same receptor subtype. Although some of melatonin's actions are mediated through its specific receptors, MT1/MT2, a considerable amount of melatonin's actions are dependent on its ability as an antioxidant.

\section{Melatonin as an antioxidant}

ROS are involved in a variety of cellular processes ranging from physiological to pathological responses. It is well-known that ROS can promote not only cell survival, proliferation and differentiation at the physiological level, but also cell death by apoptosis or necrosis at the higher level $[33,34]$. Oxidative stress can be defined as the imbalance between cellular oxidant species like ROS and antioxidants, and has a direct toxic effect on cells, which leads to lipid peroxidation, protein oxidation or DNA damage. Oxidative stress plays a causative or adjuvant role in almost all human pathologies, including cancer $[35,36]$ and neurodegeneration $[37,38]$, and is involved in aging $[39,40]$ and chronic inflammatory pathologies [41, 42].

A small percentage (an estimated 1-4\%) of the oxygen that enters cells is metabolized to derivatives which are often referred to as free radicals or ROS [43]. Mitochondria seem to be the most important subcellular site of ROS production. The mitochondrial electron transport chain with molecular oxygen directly generates the superoxide anion radical $\left(\mathrm{O}_{2}{ }^{-{ }^{-}}\right)[44,45] . \mathrm{O}_{2}{ }^{--}$is not considered to be highly reactive and, therefore, does minimal direct structural damage to molecules. $\mathrm{O}_{2}{ }^{--}$is scavenged by a specific enzyme, manganese -superoxide dismutase (Mn-SOD), to form hydrogen peroxide $\left(\mathrm{H}_{2} \mathrm{O}_{2}\right)[46,47]$. The direct toxicity of $\mathrm{H}_{2} \mathrm{O}_{2}$ to cells is limited, however, have a long half-life ( $>4 \mathrm{~s}$ ) and it can readily pass the membranes. Although $\mathrm{H}_{2} \mathrm{O}_{2}$ is also changed into $\mathrm{H}_{2} \mathrm{O}$ by glutathione peroxide $(\mathrm{GPx})$ in mitochondria [48], some part and/or excess of $\mathrm{H}_{2} \mathrm{O}_{2}$ can diffuse to cytosol, membranes and nucleus, and can be a source to increase in concentrations of ROS. $\mathrm{H}_{2} \mathrm{O}_{2}$ is readily converted to the hydroxyl radical $\left({ }^{\circ} \mathrm{OH}\right)$ when it is in the presence of a transition metal, e.g. Fe (Fenton reaction) [49]. ${ }^{\circ} \mathrm{OH}$ has a half - life shorter than $1 \mathrm{~ns}$ in an aqueous environment [50], but it is highly reactive. Thus when it is produced in vivo, it harms or destroys any molecule in the vicinity of where the radical is generated [51]. The formation of ${ }^{\circ} \mathrm{OH}$ in the vicinity of DNA might lead to this radical reacting with DNA bases or with the deoxyribose backbone of DNA to produce damaged bases or strand breaks. Since the most sensitive DNA base is $\mathrm{G}$ (guanine), hydroxyl radical reacts with guanine to form 8-hydroxy-2'-deoxyguanosine (8-OHdG). $8-\mathrm{OHdG}$ is one of the major products of DNA oxidation and a sensitive genotoxic marker of oxidatively damaged DNA [52].

It has been discovered that melatonin is a powerful free radical scavenger and a broad-spectrum antioxidant $[53,54]$. Because of its small size and highly lipophilic properties [53, 55], melatonin crosses all cell membranes and easily reaches subcellular compartments, including mitochondria and nuclei, where it seems to accumulate in high concentrations [56, 57]. Melatonin prevents lipid peroxidation [58,59], protein [60], and DNA damage [61, 62]. In particular, melatonin has been found to preserve optimal mitochondrial function 
[63-66] and homeostasis by reducing and preventing mitochondrial oxidative stress, thereby curtailing subsequent apoptotic events and cell death [53, 67, 68]. The ability of melatonin to scavenge the ${ }^{\circ} \mathrm{OH}$ is much higher than other antioxidants including mannitol, glutathione and vitamin E [69]. Melatonin is a powerful and broad antioxidant, since it has been shown to scavenge different types of free radicals including $\mathrm{O}_{2}{ }^{\cdot-}$, 'OH, singlet oxygen $\left({ }^{1} \mathrm{O}_{2}\right), \mathrm{H}_{2} \mathrm{O}_{2}$, hypochlorous acid $(\mathrm{HOCl})$, nitric oxide $\left(\mathrm{NO}^{\circ}\right)$, and the peroxynitrite anion $\left(\mathrm{ONOO}^{-}\right)$[63-66]. Not only is melatonin itself a direct free radical scavenger, but metabolites that are formed during these interactions (i.e., cyclic 3-hydroxmelatonin, N1-acetyl-N2-formyl-5-methoxykynuramine, and N1-acetyl-5-methoxykynuramine), are likewise excellent scavengers of toxic reactants [64, 70-72]. Furthermore, melatonin plays an important role in activating antioxidant defenses such as SOD, catalase (CAT), GPx, glutathione reductase (GSH-Rd) and glucose-6-phosphate dehydrogenase (G6PD) [73, 74].

\section{Ovulation and oxidative stress}

Ovulation is initiated by an LH surge and is accompanied with a variety of changes in the ovulatory follicle. The mechanism of ovulation has been compared to an inflammatory reaction [75]. Components of inflammation that are found in ovulation include increases in prostaglandin synthesis and cytokine production, the action of proteolytic enzymes, and increased vascular permeability [76-78]. ROS are important mediators of these inflammatory reactions, and they have been reported to be involved in ovulation [79]. Macrophages, neutrophils, and vascular endothelial cells reside in follicles [80], and ROS are produced by these cells during ovulation [81].

Although ROS play a role in follicle rupture during ovulation, they potentially damage oocyte and granulosa cells undergoing luteinization. ROS have been reported to inhibit progesterone production by luteal cells through the inhibition of steroidogenic enzymes [81] and intracellular carrier proteins involving transport of cholesterol to mitochondria [82]. ROS also disrupt the plasma membrane of luteal cells because of lipid peroxidation, and, as a consequence, membrane damage is often seen in the regressing corpus luteum $[83,84]$. ROS are also essential for oocyte maturation; the oxidative phosphorylation within mitochondria provides a major source of energy needed for oocyte matu- ration from the germinal vesicle $(\mathrm{GV})$ stage to mature metaphase II (MII), which is identified by the appearance of the first polar body. MII oocytes consume high levels of adenosine triphosphates (ATP) [85]. However, over production of ROS inhibit ATP synthase [86] and damage mitochondria so that ATP content of oocytes decreases $[86,87]$. The relationship between low ATP content in oocyte and poor oocyte quality has been recognized [88-90]. Excess amounts of ROS may be involved in oxidative stress and poor oocyte quality. ROS such as $\mathrm{O}_{2}{ }^{{ }^{-}},{ }^{\circ} \mathrm{OH}$, and $\mathrm{H}_{2} \mathrm{O}_{2}$ are known to be detrimental to the oocyte. They cause deterioration of cell membrane lipids, destroy DNA and induce twocell block, apoptosis, and inhibition of fertilization in mice and hamsters [91-93]. Also, higher levels of the oxidant $\mathrm{H}_{2} \mathrm{O}_{2}$ have been reported in fragmented human embryos compared with non-fragmented embryos and unfertilized oocytes [94].

Oxidative stress, a state characterized by an imbalance between pro-oxidant molecules, including reactive oxygen and nitrogen species, and antioxidant defenses, has been identified to play a key role in the pathogenesis of subfertility in both males and females. However, in females, the impact of oxidative stress on oocytes and the reproductive functions remains unclear. It has been shown that extremes of body weight and lifestyle factors such as cigarette smoking, alcohol use and recreational drug use can promote excess free radical production, which can affect fertility [95].

On the other hand, antioxidants are scavengers that detoxify excess ROS, thereby helping to maintain the body's delicate oxidant/antioxidant balance. There are two types of antioxidants: enzymatic and nonenzymatic. It is well-documented that antioxidant enzymes, such as SOD, GPx and CAT, and non-enzymatic antioxidants, such as vitamin $\mathrm{E}$, vitamin $\mathrm{C}$, glutathione, uric acid and albumin, are present in the follicles [79, 96, 97]. Reduced antioxidant enzyme levels, such as reduced levels of GPx, are reported in the follicular fluids of women with unexplained infertility [98]. Another report demonstrated that higher levels of SOD activities in follicular fluid efficiently reduced DNA damage caused by oxidative stress in porcine oocytes and cumulus cells, resulting in successful fertilization and development to the blastocyst stage after in vitro insemination; however, these abilities were interrupted by the SOD inhibitor [99]. When mice were given antioxidant supplements (vitamins $\mathrm{C}$ and $\mathrm{E}$ ), an increased number of normal MII oocytes and decreased percent- 


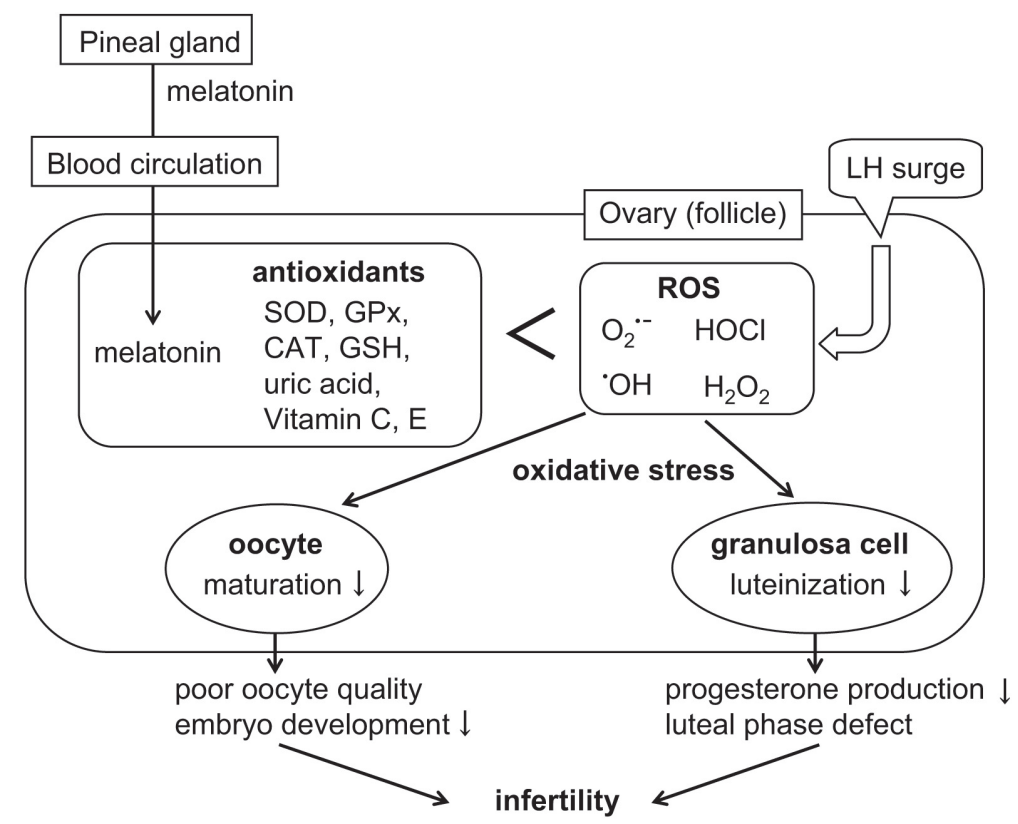

Fig. 1 The balance between ROS and antioxidants in the follicle.

ROS are produced within the follicles, especially ovulation process induced by LH surge. Antioxidant enzymes, such as superoxide dismutase (SOD), glutathione peroxidase (GPx) and catalase, and non-enzymatic antioxidants, such as vitamin E, vitamin $\mathrm{C}$, glutathione, uric acid and albumin, are present in the follicles. Melatonin, secreted by pineal gland and is taken up into the follicular fluid from the blood, is one of the antioxidant in the follicle. Excess amounts of ROS may be involved in oxidative stress of oocyte and granulosa cells. The balance between ROS and antioxidants within the follicle may be critical for oocyte maturation and luteinization of granulosa cells.

age of apoptotic oocytes were observed in comparison to the control group [100].

Infertile females seem to have an imbalance status involving increased oxidative stress and decreased antioxidants, although the underlying mechanism is unclear. However, the balance between ROS and antioxidants within the follicle seems to be critical for oocyte maturation and granulosa cells functions undergoing luteinization during ovulation. Therefore, it is likely that the balance is involved in poor oocyte quality and luteal phase defect, and it may be an important factor of female infertility (Fig. 1).

\section{Melatonin and Reproduction (ovary)}

Circadian rhythms are driven by biological oscillators (circadian clocks) that entrain to the light:dark cycle. Melatonin is a well-known transducer of light information, defining the length of the light. Melatonin plays an essential role in reproduction rhythms by acting on the hypothalamus and pars tuberalis of the pituitary, where melatonin receptors are highly expressed. Melatonin regulates gonadotropin releasing hormone
(GnRH) secretion in the hypothalamus and gonadotropin release in the pituitary gland. In addition, melatonin has recently been discovered to stimulate gonadotropin-inhibitory hormone $(\mathrm{GnIH})$, a neuropeptide that inhibits gonadotropin synthesis, release and production in the hypothalamus in birds [101]. Rats ovulate during the night after the proestrus day, and rupture of the ovarian follicles is triggered by the release of a surge of LH. However, the role of melatonin in influencing the hypothalamic-pituitary-gonadal axis in humans is less clear.

It is worth noting that melatonin concentration in human fluids can be higher than that measured in blood [102-104]. Although high concentration of melatonin in ovarian follicular fluids has been reported $[15,105]$, the role of melatonin in follicle has not been analyzed. We focused on the effect of melatonin as an antioxidant within the ovarian follicle. Previous report demonstrated the tissue distribution of $\mathrm{H}^{3}$-melatonin when given by intravenous injection to cat [106]. It was found that the concentration of $\mathrm{H}^{3}$-melatonin in the ovary was ten times higher than plasma, and high uptake of $\mathrm{H}^{3}$-melatonin by the ovary was demonstrated compared 
to other peripheral tissues. Since circulating melatonin is highly concentrated by the ovary, it is of interest in view of the relationship between melatonin and ovarian function. We previously reported the melatonin concentrations in the ovary at mid-light and mid-dark during the estrous cycle in the cyclic hamster [107]. Melatonin concentrations in the ovary showed a phasic variation as in the pineal gland and serum; they were high at mid-dark and low at mid-light. The ovarian melatonin concentration at mid-dark was significantly higher on proestrus than the other days of the estrous cycle. The ovary on proestrus has preovulatory follicles, therefore, it is likely that melatonin is taken up from the circulation by the ovary during follicular growth. We also demonstrated the melatonin concentrations in human follicular fluids in patients undergoing in-vitro fertilization and embryo transfer (IVF-ET) program [108]. Melatonin concentrations are higher in the fluid of large follicles than in the small follicles suggesting that increased melatonin in preovulatory follicles may have an important role in ovulation processes.

Some peripheral tissues like retina [109], gastrointestinal tract [110], skin [111], leukocytes [112] and bone marrow $[113,114]$ synthesize melatonin. When we checked the NAT expression of granulosa cells by PCR in rats and humans, we did not detect active NAT expression. We also measured the melatonin concentrations in human follicular fluids from the patients who were given melatonin administrations. The melatonin concentrations were increased depending on the dose of melatonin ( $1 \mathrm{mg}, 3 \mathrm{mg}$ and $6 \mathrm{mg}$ ) (unpublished data). These findings suggest that the melatonin in follicular fluid is derived from circulation and the uptake of melatonin by the ovarian follicles increased depending on follicular growth. However, the mechanism is unclear, and further studies are needed to better understand the role of melatonin in follicles.

To investigate the relationship between oxidative stress and sex steroid production, we analyzed the concentrations of an oxidative stress marker (8-OHdG), antioxidants ( $\mathrm{Cu}, \mathrm{Zn}-\mathrm{SOD}$, glutathione, melatonin), and sex steroids (progesterone, testosterone, estradiol) in mature follicles from the patients undergoing an IVF-ET program [115]. Melatonin concentrations in the follicular fluid showed a negative correlation with $8-\mathrm{OHdG}$, whereas $\mathrm{Cu}, \mathrm{Zn}$-SOD and glutathione did not show any significant correlation with 8-OHdG. Progesterone concentrations in the follicular fluid showed a positive correlation with melatonin, whereas estradiol and testosterone did not show any significant correlation with melatonin. The progesterone concentrations in the follicular fluid were negatively correlated with 8-OHdG concentrations. Our data suggest that melatonin is an important antioxidant within the follicle and contributes to progesterone production by luteinized granulosa cells.

Melatonin receptors (MT1, MT2) are expressed in ovaries in various mammalian species, including humans. Melatonin may regulate the ovarian function via activation of multiple receptors and signaling pathways in different target cell types, especially theca and granulosa cells [116]. MT1 and MT2 receptors expressed in antral follicles and the corpus luteum may affect steroidgenesis via cAMP-mediated signaling in rats [116]. An analysis of chicken ovaries revealed that only MT2, and not MT1, is expressed in small follicles. In contrast, both the MT1 and MT2 expressions are detected in preovulatory follicles [117]. In addition, the MT1 expression is detected in the thecal layer, but not in the granulosa layer. In contrast, MT2 is expressed in both granulosa and theca layers. In humans, the MT1 and MT2 gene expressions in granulosa cells have been documented with a prevalence observed in the MT1 expression [118]. Further studies are needed to better understand the mechanisms of MTs in the ovarian function.

The role of melatonin in folliculogenesis has also been reported. Melatonin combined with FSH plays an important role in early folliculogenesis to promote follicular growth in in vitro cultures of goat preantral follicles [119]. The number of large follicles is increased in melatonin-treated ewes, suggesting that melatonin is a potent regulator of follicular development [120]. Another report demonstrated that ovaries exhibit increased numbers of atretic follicles after pinealectomy [116]. The evidence suggests that melatonin is involved in folliculogenesis and follicle selection; however, little is still known about the influence of melatonin on follicle development in humans.

\section{Melatonin reduces oxidative stress in the follicle}

It would be interesting to know the physiological role of melatonin in follicular fluid, especially the high concentrations in preovulatory follicles, during ovulation processes. Oxidative stress caused by ROS during the ovulatory process is detrimental to oocytes and 
granulosa cells. The protective role of melatonin as an antioxidant within the follicle is discussed below.

\section{a) Oocyte}

Oxidative stress in the oocyte caused by ROS must be limited in order for a good embryo to be produced. ROS induce lipid peroxidation of membranes and DNA damage in the oocyte and are expected to cause harmful effects in cell division, metabolite transport, and mitochondrial function [121]. We recently reported the direct effect of ROS and melatonin on oocyte maturation [122]. To investigate the effects of $\mathrm{H}_{2} \mathrm{O}_{2}$ on oocyte maturation, the denuded oocytes from immature mice treated with PMSG were cultured in the incubation medium with various concentrations of $\mathrm{H}_{2} \mathrm{O}_{2}$. After $12 \mathrm{hr}$ incubation, oocytes with the first polar body (MII stage oocytes) were counted. The percentage of the mature oocytes (MII stage oocytes with a first polar body) was significantly decreased by the addition of $\mathrm{H}_{2} \mathrm{O}_{2}$ in a dose-dependent manner $(>200$ $\mu \mathrm{M})$. When oocytes were incubated with melatonin in the presence of $\mathrm{H}_{2} \mathrm{O}_{2}(300 \mu \mathrm{M})$, melatonin dosedependently blocked the inhibitory effect of $\mathrm{H}_{2} \mathrm{O}_{2}$ on oocyte maturation, and there was a significant effect at the concentration of $10 \mathrm{ng} / \mathrm{mL}$ of melatonin. To further investigate the intra-cellular role of melatonin, oocytes were incubated with dichlorofluorescein (DCF-DA). The nonfluorescent DCF-DA was oxidized by intracellular ROS to form the highly fluorescent DCF, intracellular ROS formation was visualized by fluorescence image, and fluorescence intensity was analyzed [123]. When oocytes were incubated without $\mathrm{H}_{2} \mathrm{O}_{2}$, there was no observable fluorescent intensity. However, high fluorescence intensities were observed in the presence of $\mathrm{H}_{2} \mathrm{O}_{2}(300 \mu \mathrm{m})$. The increased fluorescence intensity of oocytes incubated with $\mathrm{H}_{2} \mathrm{O}_{2}$ was significantly decreased by melatonin treatment. These results suggest that $\mathrm{H}_{2} \mathrm{O}_{2}$ inhibits oocytes maturation by producing ROS, but melatonin demonstrated protective activity against oxidative stress caused by $\mathrm{H}_{2} \mathrm{O}_{2}$. Recently, Kang et al., [124] investigated the effects of melatonin on the maturation of porcine oocytes. Oocytes from antral follicles were incubated in the medium with or without melatonin supplementation. Melatonin supplementation $(10 \mathrm{ng} / \mathrm{mL})$ during in-vitro maturation resulted in a greater proportion of oocytes extruding the polar body, and melatonin-treated oocytes had significantly lower levels of ROS than control (without melatonin treatment) oocytes.
The ability of melatonin to promote embryo development in different species has been reported. When inseminated mouse embryos were cultured in the medium with melatonin $\left(10^{-8}-10^{-4} \mathrm{M}\right)$, increased fertilization and blastocyst rates were observed [125]. Rodriguez-Osorio et al. [126] demonstrated the effects of melatonin on in-vitro porcine embryo development. Melatonin supplementation $\left(10^{-9} \mathrm{M}\right)$ had a positive effect on the fertilization rates of inseminated porcine embryos that were cultured. Although blastocyst rates were not increased by melatonin, the number of blastocyst cells in the melatonin-supplemented group was significantly higher than in the control group. When the oocytes recovered from porcine follicles were incubated in the medium with melatonin $\left(10^{-7} \mathrm{M}\right)$, fertilization rate, blastocyst rate and the number of blastocyst cells were significantly higher than that of the control (without melatonin) [127]. The effect of melatonin on embryo development seems to be, at least in part, caused by its action as an antioxidant, as Papis et al. [128] demonstrated that the beneficial effects of melatonin on bovine embryo development was observed not in a low oxygen environment but in a high oxygen environment where free radicals are easily produced. We recently confirmed the benefit of melatonin treatment to infertility women who underwent an IVF-ET program. When women were treated with $3 \mathrm{mg}$ of melatonin daily from day 5 of the previous menstrual cycle until the day of oocyte retrieval, the percentage of good embryos (day 2 after insemination) was significantly higher compared to the control (without melatonin treatment) cycle [123]. These data suggest that melatonin may be involved in oocyte maturation and embryo development.

\section{b) Granulosa cells}

In ovaries, the corpus luteum is formed after ovulation and produces progesterone, which is necessary for establishment and maintenance of pregnancy. Although ROS play a role in follicle rupture during ovulation, they potentially damage granulosa cells undergoing luteinization. ROS have been reported to inhibit progesterone production by luteal cells [81], mediated by inhibition of steroidogenic enzymes and intracellular carrier proteins involving transport of cholesterol to mitochondria [82]. ROS also disrupt the plasma membrane of luteal cells because of lipid peroxidation, and, as a consequence, damaged membrane changes are often seen in the regressing corpus luteum $[83,84]$. 
To examine the effect of melatonin on progesterone production, luteinized granulosa cells were obtained at the time of oocyte retrieval in women undergoing IVF-ET. Luteinized granulosa cells were incubated with or without $\mathrm{H}_{2} \mathrm{O}_{2}(30,50$, or $100 \mu \mathrm{M})$ in serumfree incubation medium for $12 \mathrm{~h}$ in the presence or absence of melatonin $(1,10,100 \mu \mathrm{g} / \mathrm{mL})$. After incubation, the progesterone concentration in culture medium was measured. Progesterone production was significantly inhibited by $\mathrm{H}_{2} \mathrm{O}_{2}(30 \mu \mathrm{M}: 54.9 \pm 18.8 \%$; $50 \mu \mathrm{M}: 30.1 \pm 18.8 \% ; 100 \mu \mathrm{M}$ : $17.4 \pm 6.0 \%$, values are mean \pm SEM), and the inhibitory effect of $\mathrm{H}_{2} \mathrm{O}_{2}$ on progesterone production was reversed by addition of melatonin $(0 \mu \mathrm{g} / \mathrm{mL}: 21.4 \pm 2.8 \% ; 1 \mu \mathrm{g} / \mathrm{mL}: 38.0$ $\pm 7.8 \% ; 10 \mu \mathrm{g} / \mathrm{mL}: 65.5 \pm 22.1 \% ; 100 \mu \mathrm{g} / \mathrm{mL}: 99.7$ $\pm 31.4 \%$, values are mean \pm SEM) [115]. Our results also showed that ROS reduced progesterone production by luteinized granulosa cells, however, melatonin abolished the inhibitory effect of $\mathrm{H}_{2} \mathrm{O}_{2}$ on progesterone production. Therefore, the study suggests that melatonin protects granulosa cells from ROS in the follicle during ovulation and contributes to luteinization of granulosa cells.

\section{Melatonin treatment for infertility women}

\section{a) Oocyte quality}

As summarized above, a growing amount of literature has demonstrated that melatonin and/or melatonin treatment may have a beneficial effect on oocyte maturation and embryo development. Poor oocyte quality is one of the most intractable causes of infertility in women. Melatonin treatment can be a useful infertility treatment and, therefore recently has been applied to infertility patients for the first time.

To document an association between melatonin and ovarian oxidative stress, human follicular fluids were sampled during oocyte retrieval for the purpose of IVF-ET and concentrations of melatonin and 8-OHdG were measured. The study revealed an inverse correlation between intra-follicular concentrations of melatonin and $8-\mathrm{OHdG}$, suggesting that melatonin in the follicle diffuses into the cumulus and oocytes to protect them from free radical damage. When patients were given a $3 \mathrm{mg}$ tablet of melatonin orally at 22:00 $\mathrm{hr}$ from the fifth day of the previous menstrual cycle until the day of oocyte retrieval, intra-follicular concentrations of melatonin rose from $112 \mathrm{pg} / \mathrm{mL}$ in the control cycle (without melatonin treatment) to $432 \mathrm{pg} /$
$\mathrm{mL}$ after daily melatonin treatment $[122,129]$. Intrafollicular concentrations of $8-\mathrm{OHdG}$ and hexanoyllysine adduct (HEL), a damaged lipid product, were decreased after melatonin treatment compared to those in the prior cycle. The result demonstrates that melatonin treatment reduces intra-follicular oxidative damage. To investigate the clinical usefulness of melatonin administration, the effect of melatonin treatment on clinical outcome of IVF-ET was examined for 115 patients who failed to become pregnant in the previous IVF-ET cycle with a low fertilization rate $(<50 \%)$. In 56 patients with melatonin treatment, the fertilization rate $(50.0 \pm 38.0 \%)$ was markedly improved compared with the previous IVF-ET cycle $(20.2 \pm 19.0 \%)$, and 11 of 56 patients $(19.6 \%)$ achieved pregnancy. On the other hand, in 59 patients who were not given melatonin, the fertilization rate $(22.8 \pm 19.0 \%$ vs $20.9 \pm 16.5 \%)$ was not significantly changed, and only 6 of 59 patients $(10.2 \%)$ achieved pregnancy $[122,129]$. These results show that melatonin administration increases intra-follicular melatonin concentrations, reduces intra-follicular oxidative damage and elevates fertilization and pregnancy rates.

To our knowledge, our study represents the first clinical usefulness of melatonin treatment for infertility patients. Melatonin is likely to become a treatment for improving oocyte quality for women who cannot become pregnant because of poor oocyte quality.

\section{b) Luteal function}

Luteal phase defect has been implicated as a cause of infertility and spontaneous miscarriage. However, the etiology of luteal phase defect is complicated by the fact that the causes of luteal phase defect are highly varied. Not only Low blood flow of the corpus luteum $[130,131]$ but also oxidative stress $[132,133]$ are associated with luteal phase defect. Serum lipid peroxide levels were significantly elevated in patients with luteal phase defect compared to women with normal luteal function [134]. In addition, ascorbic acid (antioxidant) supplementation improved serum progesterone levels in patients with luteal phase defect [135]. These findings suggest that oxidative stress caused by ROS is one of the important causes of luteal phase defect.

To analyze the clinical effectiveness of melatonin administration in patients with luteal phase defect, twenty-five infertility patients (aged 26-42 yr) with luteal phase defect who did not have decreased luteal blood flow were enrolled [115]. These patients were 
diagnosed as having luteal phase defect (serum progesterone concentrations during the mid-luteal phase were $<10 \mathrm{ng} / \mathrm{mL}$ ), and were not diagnosed as having decreased luteal blood flow. Patients were divided into two groups during the subsequent treatment cycle; 14 women were given $3 \mathrm{mg}$ /day of melatonin orally at 22:00h after hCG injection $(5,000 \mathrm{IU}, \mathrm{im})$ throughout the luteal phase, and 11 women were given no medication after hCG injection as a control. Venous blood samples were obtained for progesterone assay during the mid-luteal phase (6-8 days after ovulation). When 14 women who had luteal phase defect were given melatonin throughout the luteal phase of the subsequent menstrual cycle, nine patients $(64.3 \%)$ showed improved serum progesterone concentrations of more than $10 \mathrm{ng} / \mathrm{mL}$, and the mean progesterone concentration was $11.0 \pm 2.6 \mathrm{ng} / \mathrm{mL}$. In the control group without melatonin treatment, only two patients out of 11 (18.2\%) showed normal serum progesterone concentrations, and the mean progesterone concentration was $8.9 \pm 2.2 \mathrm{ng} / \mathrm{mL}$. The improvement rates of the two groups were significantly different $(p<0.05)$. The result strongly suggests that oxidative stress is one of the causes of luteal phase defect, and melatonin protects luteinized granulosa cells and increases progesterone production of corpus luteum by reducing oxidative stress. Melatonin supplementation can be a useful treatment for luteal phase defect that is related to oxidative stress.

\section{Conclusions}

The discovery of melatonin as a direct free radical scavenger has greatly broadened the understanding of its multiple physiological roles. The new findings regarding the potential role of melatonin in reproductive physiology have also been increasing. Melatonin is applicable to the regulation of seasonal reproductive events in photoperiod dependent breeding mam- mals. The regulation of seasonal reproductive events seems to be mediated by receptors (MT1/MT2) in the hypothalamus and pituitary gland. However, recently many researchers have begun to study the local role of melatonin as an antioxidant. We focused on intrafollicular role of melatonin in the ovary. Melatonin, secreted by the pineal gland, is taken up into the follicular fluid from the blood. ROS produced within the follicles, especially during the ovulation process, were scavenged by melatonin, and reduced oxidative stress may be involved in oocyte maturation, embryo development and luteinaization of granulosa cells (Fig. 1). Our clinical study demonstrated that melatonin treatment for infertile women increases intra-follicular melatonin concentrations, reduces intra-follicular oxidative damage and elevates fertilization and pregnancy rates. Melatonin treatment also improves progesterone production by corpus luteum in infertile women with luteal phase defect. The safety of exogenous melatonin for humans has been shown in many studies [136, 137]. It has also been reported that melatonin has no detrimental effects on mouse and rat embryo development during toxicity tests that were performed both invitro and in-vivo [124, 138, 139]. It should be noted that melatonin treatment could become a new cure for improving oocyte quality in infertile women.

\section{Acknowledgements}

The authors would like to thank Dr. Russel J Reiter (Department of Cellular \& Structural Biology, The University of Texas Health Science Center, San Antonio, TX, USA) and Dr. Yasuhiko Nakamura (Department of Obstetrics and Gynecology, Yamaguchi Grand Medical Center, Hofu, Japan) for their advice. This work was supported in part by Grants-in-Aid 20591918, 21592099, and 21791559 for Scientific Research from the Ministry of Education, Culture, Sports, Science and Technology of Japan.

\section{References}

1. Reiter RJ (1993) The melatonin rhythm: both a clock and a calendar. Experientia 49: 654-664.

2. Reiter RJ, Rosales-Corral S, Coto-Montes A, Boga JA, Tan DX, Davis JM, Konturek PC, Konturek SJ, and Brzozowski T (2011) The photoperiod, circadian regulation and chronodisruption: the requisite interplay between the suprachiasmatic nuclei and the pineal and gut melatonin. J Physiol Pharmacol 62: 269-274.

3. Kappers JA (1976) The mammalian pineal gland, a survey. Acta Neurochir (Wien) 34: 109-149.

4. Moore RY (1978) Neural control of pineal function in mammals and birds. J Neural Transm Suppl 47-58. 
5. Reiter RJ (1991) Melatonin: the chemical expression of darkness. Mol Cell Endocrinol 79: C153-158.

6. Hardeland R (2008) Melatonin, hormone of darkness and more: occurrence, control mechanisms, actions and bioactive metabolites. Cell Mol Life Sci 65: 2001-2018.

7. Klein DC (2007) Arylalkylamine N-acetyltransferase: "the Timezyme". J Biol Chem 282: 4233-4237.

8. Ceinos RM, Chansard M, Revel F, Calgari C, Miguez JM, and Simonneaux V (2004) Analysis of adrenergic regulation of melatonin synthesis in Siberian hamster pineal emphasizes the role of HIOMT. Neurosignals 13: 308-317.

9. Ribelayga C, Pevet P, and Simonneaux V (2000) HIOMT drives the photoperiodic changes in the amplitude of the melatonin peak of the Siberian hamster. Am J Physiol Regul Integr Comp Physiol 278: R1339-1345.

10. Koppisetti S, Jenigiri B, Terron MP, Tengattini S, Tamura H, Flores LJ, Tan DX, and Reiter RJ (2008) Reactive oxygen species and the hypomotility of the gall bladder as targets for the treatment of gallstones with melatonin: a review. Dig Dis Sci 53: 2592-2603.

11. Rousseau A, Petren S, Plannthin J, Eklundh T, and Nordin C (1999) Serum and cerebrospinal fluid concentrations of melatonin: a pilot study in healthy male volunteers. J Neural Transm 106: 883-888.

12. Vakkuri O (1985) Diurnal rhythm of melatonin in human saliva. Acta Physiol Scand 124: 409-412.

13. Bornman MS, Oosthuizen JM, Barnard HC, Schulenburg GW, Boomker D, and Reif S (1989) Melatonin and sperm motility. Andrologia 21: 483-485.

14. Kivela A, Kauppila A, Leppaluoto J, and Vakkuri O (1989) Serum and amniotic fluid melatonin during human labor. J Clin Endocrinol Metab 69: 1065-1068.

15. Brzezinski A, Seibel MM, Lynch HJ, Deng MH, and Wurtman RJ (1987) Melatonin in human preovulatory follicular fluid. J Clin Endocrinol Metab 64: 865-867.

16. Agez L, Laurent V, Guerrero HY, Pevet P, Masson-Pevet M, and Gauer F (2009) Endogenous melatonin provides an effective circadian message to both the suprachiasmatic nuclei and the pars tuberalis of the rat. $J$ Pineal Res 46: 95-105.

17. Arendt J (2000) Melatonin, circadian rhythms, and sleep. N Engl J Med 343: 1114-1116.

18. Fisher SP, Davidson K, Kulla A, and Sugden D (2008) Acute sleep-promoting action of the melatonin agonist, ramelteon, in the rat. J Pineal Res 45: 125-132.

19. van Geijlswijk IM, Korzilius HP, and Smits MG (2010) The use of exogenous melatonin in delayed sleep phase disorder: a meta-analysis. Sleep 33: 1605-1614.

20. Carrillo-Vico A, Reiter RJ, Lardone PJ, Herrera JL, Fernandez-Montesinos R, Guerrero JM, and Pozo D (2006) The modulatory role of melatonin on immune responsiveness. Curr Opin Investig Drugs 7: 423-431.

21. Guerrero JM, and Reiter RJ (2002) Melatonin-immune system relationships. Curr Top Med Chem 2: 167-179.
22. Scheer FA, Van Montfrans GA, van Someren EJ, Mairuhu G, and Buijs RM (2004) Daily nighttime melatonin reduces blood pressure in male patients with essential hypertension. Hypertension 43: 192-197.

23. Simko F, and Pechanova O (2009) Potential roles of melatonin and chronotherapy among the new trends in hypertension treatment. J Pineal Res 47: 127-133.

24. Reiter RJ (1974) Circannual reproductive rhythms in mammals related to photoperiod and pineal function: a review. Chronobiologia 1: 365-395.

25. Reiter RJ, Tan DX, Manchester LC, Paredes SD, Mayo JC, and Sainz RM (2009) Melatonin and reproduction revisited. Biol Reprod 81: 445-456.

26. Tamarkin L, Baird CJ, and Almeida OF (1985) Melatonin: a coordinating signal for mammalian reproduction? Science 227: 714-720.

27. Blask DE, Dauchy RT, Brainard GC, and Hanifin JP (2009) Circadian stage-dependent inhibition of human breast cancer metabolism and growth by the nocturnal melatonin signal: consequences of its disruption by light at night in rats and women. Integr Cancer Ther 8: 347-353.

28. Cos S, Gonzalez A, Martinez-Campa C, Mediavilla MD, Alonso-Gonzalez C, and Sanchez-Barcelo EJ (2006) Estrogen-signaling pathway: a link between breast cancer and melatonin oncostatic actions. Cancer Detect Prev 30: 118-128.

29. Hill SM, Frasch T, Xiang S, Yuan L, Duplessis T, and Mao L (2009) Molecular mechanisms of melatonin anticancer effects. Integr Cancer Ther 8: 337-346.

30. Maldonado MD, Perez-San-Gregorio MA, and Reiter RJ (2009) The role of melatonin in the immuno-neuropsychology of mental disorders. Recent Pat CNS Drug Discov 4: 61-69.

31. Morera AL, and Abreu P (2006) Seasonality of psychopathology and circannual melatonin rhythm. J Pineal Res 41: 279-283.

32. Luchetti F, Canonico B, Betti M, Arcangeletti M, Pilolli F, Piroddi M, Canesi L, Papa S, and Galli F (2010) Melatonin signaling and cell protection function. FASEB J 24: 3603-3624.

33. Droge W (2002) Free radicals in the physiological control of cell function. Physiol Rev 82: 47-95.

34. Yao H, Guo L, Jiang BH, Luo J, and Shi X (2008) Oxidative stress and chromium(VI) carcinogenesis. $J$ Environ Pathol Toxicol Oncol 27: 77-88.

35. Farinati F, Piciocchi M, Lavezzo E, Bortolami M, and Cardin R (2010) Oxidative stress and inducible nitric oxide synthase induction in carcinogenesis. Dig Dis 28: 579-584.

36. Ziech D, Franco R, Pappa A, and Panayiotidis MI (2011) Reactive oxygen species (ROS)--induced genetic and epigenetic alterations in human carcinogenesis. Mutat Res 711: 167-173.

37. Agostinho P, Cunha RA, and Oliveira C (2010) 
Neuroinflammation, oxidative stress and the pathogenesis of Alzheimer's disease. Curr Pharm Des 16: 27662778.

38. Ventura I, Russo MT, De Luca G, and Bignami M (2010) Oxidized purine nucleotides, genome instability and neurodegeneration. Mutat Res 703: 59-65.

39. Romano AD, Serviddio G, de Matthaeis A, Bellanti F, and Vendemiale $\mathrm{G}$ (2010) Oxidative stress and aging. $J$ Nephrol 23 Suppl 15: S29-36.

40. Sohal RS, and Orr WC (2012) The redox stress hypothesis of aging. Free Radic Biol Med 52: 539-555.

41. Naik E, and Dixit VM (2011) Mitochondrial reactive oxygen species drive proinflammatory cytokine production. J Exp Med 208: 417-420.

42. Renke J, Popadiuk S, Wozniak M, SzlagatysSidorkiewicz A, and Hansdorfer-Korzon R (2006) Mast cells, their adenosine receptors and reactive oxygen species in chronic inflammatory pathologies of childhood. Przegl Lek 63: 554-556.

43. Cadenas E, and Davies KJ (2000) Mitochondrial free radical generation, oxidative stress, and aging. Free Radic Biol Med 29: 222-230.

44. Boveris A (1984) Determination of the production of superoxide radicals and hydrogen peroxide in mitochondria. Methods Enzymol 105: 429-435.

45. Han D, Antunes F, Canali R, Rettori D, and Cadenas E (2003) Voltage-dependent anion channels control the release of the superoxide anion from mitochondria to cytosol. J Biol Chem 278: 5557-5563.

46. Buettner GR (2011) Superoxide dismutase in redox biology: the roles of superoxide and hydrogen peroxide. Anticancer Agents Med Chem 11: 341-346.

47. Dikalov S (2011) Cross talk between mitochondria and NADPH oxidases. Free Radic Biol Med 51: 12891301.

48. Day BJ (2009) Catalase and glutathione peroxidase mimics. Biochem Pharmacol 77: 285-296.

49. Brillas E, Sires I, and Oturan MA (2009) Electro-Fenton process and related electrochemical technologies based on Fenton's reaction chemistry. Chem Rev 109: 65706631.

50. Valko M, Leibfritz D, Moncol J, Cronin MT, Mazur M, and Telser J (2007) Free radicals and antioxidants in normal physiological functions and human disease. Int J Biochem Cell Biol 39: 44-84.

51. Poeggeler B, Reiter RJ, Tan DX, Chen LD, and Manchester LC (1993) Melatonin, hydroxyl radicalmediated oxidative damage, and aging: a hypothesis. $J$ Pineal Res 14: 151-168.

52. Valko M, Rhodes CJ, Moncol J, Izakovic M, and Mazur M (2006) Free radicals, metals and antioxidants in oxidative stress-induced cancer. Chem Biol Interact 160: $1-40$.

53. Paradies G, Petrosillo G, Paradies V, Reiter RJ, and Ruggiero FM (2010) Melatonin, cardiolipin and mito- chondrial bioenergetics in health and disease. J Pineal Res 48: 297-310.

54. Tan DX, Manchester LC, Terron MP, Flores LJ, and Reiter RJ (2007) One molecule, many derivatives: a never-ending interaction of melatonin with reactive oxygen and nitrogen species? J Pineal Res 42: 28-42.

55. Reiter RJ, Paredes SD, Manchester LC, and Tan DX (2009) Reducing oxidative/nitrosative stress: a newlydiscovered genre for melatonin. Crit Rev Biochem Mol Biol 44: 175-200.

56. Leon J, Acuna-Castroviejo D, Escames G, Tan DX, and Reiter RJ (2005) Melatonin mitigates mitochondrial malfunction. J Pineal Res 38: 1-9.

57. Martin M, Macias M, Escames G, Leon J, and AcunaCastroviejo D (2000) Melatonin but not vitamins C and $\mathrm{E}$ maintains glutathione homeostasis in t-butyl hydroperoxide-induced mitochondrial oxidative stress. FASEB J 14: 1677-1679.

58. Akbulut KG, Gonul B, and Akbulut H (2009) The role of melatonin on gastric mucosal cell proliferation and telomerase activity in ageing. J Pineal Res 47: 308312.

59. Carretero M, Escames G, Lopez LC, Venegas C, Dayoub JC, Garcia L, and Acuna-Castroviejo D (2009) Longterm melatonin administration protects brain mitochondria from aging. J Pineal Res 47: 192-200.

60. Ganguly K, and Swarnakar S (2009) Induction of matrix metalloproteinase- 9 and -3 in nonsteroidal anti-inflammatory drug-induced acute gastric ulcers in mice: regulation by melatonin. J Pineal Res 47: 43-55.

61. Tajes Orduna M, Pelegri Gabalda C, Vilaplana Hortensi J, Pallas Lliberia M, and Camins Espuny A (2009) An evaluation of the neuroprotective effects of melatonin in an in vitro experimental model of age-induced neuronal apoptosis. J Pineal Res 46: 262-267.

62. Yamamoto HA, and Mohanan PV (2002) Melatonin attenuates brain mitochondria DNA damage induced by potassium cyanide in vivo and in vitro. Toxicology 179 : 29-36.

63. Allegra M, Reiter RJ, Tan DX, Gentile C, Tesoriere L, and Livrea MA (2003) The chemistry of melatonin's interaction with reactive species. J Pineal Res 34: 1-10.

64. Hardeland R (2005) Antioxidative protection by melatonin: multiplicity of mechanisms from radical detoxification to radical avoidance. Endocrine 27: 119-130.

65. Reiter RJ, Tan DX, Gitto E, Sainz RM, Mayo JC, Leon J, Manchester LC, Vijayalaxmi, Kilic E, and Kilic U (2004) Pharmacological utility of melatonin in reducing oxidative cellular and molecular damage. Pol $J$ Pharmacol 56: 159-170.

66. Tan DX, Manchester LC, Sainz RM, Mayo JC, Leon J, Hardeland R, Poeggeler B, and Reiter RJ (2005) Interactions between melatonin and nicotinamide nucleotide: NADH preservation in cells and in cell-free systems by melatonin. J Pineal Res 39: 185-194. 
67. Jou MJ, Peng TI, Yu PZ, Jou SB, Reiter RJ, Chen JY, Wu HY, Chen CC, and Hsu LF (2007) Melatonin protects against common deletion of mitochondrial DNAaugmented mitochondrial oxidative stress and apoptosis. J Pineal Res 43: 389-403.

68. Milczarek R, Hallmann A, Sokolowska E, Kaletha $\mathrm{K}$, and Klimek J (2010) Melatonin enhances antioxidant action of alpha-tocopherol and ascorbate against NADPH- and iron-dependent lipid peroxidation in human placental mitochondria. J Pineal Res 49: 149155.

69. Reiter RJ, Tan DX, Manchester LC, and Qi W (2001) Biochemical reactivity of melatonin with reactive oxygen and nitrogen species: a review of the evidence. Cell Biochem Biophys 34: 237-256.

70. Manda K, Ueno M, and Anzai K (2007) AFMK, a melatonin metabolite, attenuates $\mathrm{X}$-ray-induced oxidative damage to DNA, proteins and lipids in mice. $J$ Pineal Res 42: 386-393.

71. Rosen J, Than NN, Koch D, Poeggeler B, Laatsch H, and Hardeland R (2006) Interactions of melatonin and its metabolites with the ABTS cation radical: extension of the radical scavenger cascade and formation of a novel class of oxidation products. C2-substituted 3-indolinones. J Pineal Res 41: 374-381.

72. Silva SO, Rodrigues MR, Carvalho SR, Catalani LH, Campa A, and Ximenes VF (2004) Oxidation of melatonin and its catabolites, N1-acetyl-N2 -formyl-5-methoxykynuramine and N1-acetyl-5-methoxykynuramine, by activated leukocytes. J Pineal Res 37: 171-175.

73. Mayo JC, Sainz RM, Antoli I, Herrera F, Martin V, and Rodriguez C (2002) Melatonin regulation of antioxidant enzyme gene expression. Cell Mol Life Sci 59: 1706-1713.

74. Rodriguez C, Mayo JC, Sainz RM, Antolin I, Herrera F, Martin V, and Reiter RJ (2004) Regulation of antioxidant enzymes: a significant role for melatonin. J Pineal Res 36: 1-9.

75. Espey LL (1994) Current status of the hypothesis that mammalian ovulation is comparable to an inflammatory reaction. Biol Reprod 50: 233-238.

76. Brannstrom M, and Enskog A (2002) Leukocyte networks and ovulation. J Reprod Immunol 57: 47-60.

77. Richards JS (2005) Ovulation: new factors that prepare the oocyte for fertilization. Mol Cell Endocrinol 234: 75-79.

78. Tamanini C, and De Ambrogi M (2004) Angiogenesis in developing follicle and corpus luteum. Reprod Domest Anim 39: 206-216.

79. Agarwal A, Gupta S, and Sharma RK (2005) Role of oxidative stress in female reproduction. Reprod Biol Endocrinol 3: 28.

80. Brannstrom M, and Norman RJ (1993) Involvement of leukocytes and cytokines in the ovulatory process and corpus luteum function. Hum Reprod 8: 1762-1775.
81. Behrman HR, Kodaman PH, Preston SL, and Gao S (2001) Oxidative stress and the ovary. J Soc Gynecol Investig 8: S40-42.

82. Behrman HR, and Aten RF (1991) Evidence that hydrogen peroxide blocks hormone-sensitive cholesterol transport into mitochondria of rat luteal cells. Endocrinology 128: 2958-2966.

83. Gatzuli E, Aten RF, and Behrman HR (1991) Inhibition of gonadotropin action and progesterone synthesis by xanthine oxidase in rat luteal cells. Endocrinology 128: 2253-2258.

84. Vega M, Carrasco I, Castillo T, Troncoso JL, Videla LA, and Devoto L (1995) Functional luteolysis in response to hydrogen peroxide in human luteal cells. J Endocrinol 147: 177-182.

85. Dumollard R, Campbell K, Halet G, Carroll J, and Swann K (2008) Regulation of cytosolic and mitochondrial ATP levels in mouse eggs and zygotes. Dev Biol 316: 431-440.

86. Lawlor DW, and Tezara W (2009) Causes of decreased photosynthetic rate and metabolic capacity in water-deficient leaf cells: a critical evaluation of mechanisms and integration of processes. Ann Bot 103: 561-579.

87. Van Blerkom J, Davis PW, and Lee J (1995) ATP content of human oocytes and developmental potential and outcome after in-vitro fertilization and embryo transfer. Hum Reprod 10: 415-424.

88. Combelles CM, and Albertini DF (2003) Assessment of oocyte quality following repeated gonadotropin stimulation in the mouse. Biol Reprod 68: 812-821.

89. Wang LY, Wang DH, Zou XY, and Xu CM (2009) Mitochondrial functions on oocytes and preimplantation embryos. J Zhejiang Univ Sci B 10: 483-492.

90. Zeng HT, Ren Z, Yeung WS, Shu YM, Xu YW, Zhuang GL, and Liang XY (2007) Low mitochondrial DNA and ATP contents contribute to the absence of birefringent spindle imaged with PolScope in in vitro matured human oocytes. Hum Reprod 22: 1681-1686.

91. Kowaltowski AJ, and Vercesi AE (1999) Mitochondrial damage induced by conditions of oxidative stress. Free Radic Biol Med 26: 463-471.

92. Noda Y, Matsumoto H, Umaoka Y, Tatsumi K, Kishi J, and Mori T (1991) Involvement of superoxide radicals in the mouse two-cell block. Mol Reprod Dev 28: 356360 .

93. Zuelke KA, Jones DP, and Perreault SD (1997) Glutathione oxidation is associated with altered microtubule function and disrupted fertilization in mature hamster oocytes. Biol Reprod 57: 1413-1419.

94. Yang HW, Hwang KJ, Kwon HC, Kim HS, Choi KW, and Oh KS (1998) Detection of reactive oxygen species (ROS) and apoptosis in human fragmented embryos. Hum Reprod 13: 998-1002.

95. Agarwal A, Aponte-Mellado A, Premkumar BJ, Shaman A, and Gupta S (2012) The effects of oxidative stress on 
female reproduction: a review. Reprod Biol Endocrinol 10: 49 .

96. Al-Gubory KH, Bolifraud P, Germain G, Nicole A, and Ceballos-Picot I (2004) Antioxidant enzymatic defence systems in sheep corpus luteum throughout pregnancy. Reproduction 128: 767-774.

97. Goud AP, Goud PT, Diamond MP, Gonik B, and AbuSoud HM (2008) Reactive oxygen species and oocyte aging: role of superoxide, hydrogen peroxide, and hypochlorous acid. Free Radic Biol Med 44: 12951304.

98. Paszkowski T, Traub AI, Robinson SY, and McMaster D (1995) Selenium dependent glutathione peroxidase activity in human follicular fluid. Clin Chim Acta 236: 173-180.

99. Tatemoto H, Muto N, Sunagawa I, Shinjo A, and Nakada T (2004) Protection of porcine oocytes against cell damage caused by oxidative stress during in vitro maturation: role of superoxide dismutase activity in porcine follicular fluid. Biol Reprod 71: 1150-1157.

100. Tarin JJ, Perez-Albala S, and Cano A (2002) Oral antioxidants counteract the negative effects of female aging on oocyte quantity and quality in the mouse. Mol Reprod Dev 61: 385-397.

101. Tsutsui K, Bentley GE, Bedecarrats G, Osugi T, Ubuka T, and Kriegsfeld LJ (2010) Gonadotropin-inhibitory hormone $(\mathrm{GnIH})$ and its control of central and peripheral reproductive function. Front Neuroendocrinol 31: 284-295.

102. Reiter RJ, and Tan DX (2002) Role of CSF in the transport of melatonin. $J$ Pineal Res 33: 61.

103. Tan DX, Manchester LC, Reiter RJ, Qi W, Hanes MA, and Farley NJ (1999) High physiological levels of melatonin in the bile of mammals. Life Sci 65: 2523-2529.

104. Tan DX, Manchester LC, Sanchez-Barcelo E, Mediavilla MD, and Reiter RJ (2010) Significance of high levels of endogenous melatonin in Mammalian cerebrospinal fluid and in the central nervous system. Curr Neuropharmacol 8: 162-167.

105. Ronnberg L, Kauppila A, Leppaluoto J, Martikainen H, and Vakkuri O (1990) Circadian and seasonal variation in human preovulatory follicular fluid melatonin concentration. J Clin Endocrinol Metab 71: 492-496.

106. Wurtman RJ, Axelrod J, and Potter LT (1964) THE UPTAKE OF H3-MELATONIN IN ENDOCRINE AND NERVOUS TISSUES AND THE EFFECTS OF CONSTANT LIGHT EXPOSURE. $J$ Pharmacol Exp Ther 143: 314-318.

107. Tamura H, Nakamura Y, Takiguchi S, Kashida S, Yamagata Y, Sugino N, and Kato H (1998) Melatonin directly suppresses steroid production by preovulatory follicles in the cyclic hamster. $J$ Pineal Res 25: 135141.

108. Nakamura $\mathrm{Y}$, Tamura H, Takayama H, and Kato H (2003) Increased endogenous level of melatonin in pre- ovulatory human follicles does not directly influence progesterone production. Fertil Steril 80: 1012-1016.

109. Faillace MP, Cutrera R, Sarmiento MI, and Rosenstein RE (1995) Evidence for local synthesis of melatonin in golden hamster retina. Neuroreport 6: 2093-2095.

110. Bubenik GA (2002) Gastrointestinal melatonin: localization, function, and clinical relevance. Dig Dis Sci 47: 2336-2348.

111. Slominski A, Pisarchik A, Semak I, Sweatman T, Wortsman J, Szczesniewski A, Slugocki G, McNulty J, Kauser S, Tobin DJ, Jing C, and Johansson O (2002) Serotoninergic and melatoninergic systems are fully expressed in human skin. FASEB J 16: 896-898.

112. Carrillo-Vico A, Calvo JR, Abreu P, Lardone PJ, GarciaMaurino S, Reiter RJ, and Guerrero JM (2004) Evidence of melatonin synthesis by human lymphocytes and its physiological significance: possible role as intracrine, autocrine, and/or paracrine substance. FASEB J 18: 537539.

113. Conti A, Conconi S, Hertens E, Skwarlo-Sonta K, Markowska M, and Maestroni JM (2000) Evidence for melatonin synthesis in mouse and human bone marrow cells. J Pineal Res 28: 193-202.

114. Tan DX, Manchester LC, Reiter RJ, Qi WB, Zhang M, Weintraub ST, Cabrera J, Sainz RM, and Mayo JC (1999) Identification of highly elevated levels of melatonin in bone marrow: its origin and significance. Biochim Biophys Acta 1472: 206-214.

115. Taketani T, Tamura H, Takasaki A, Lee L, Kizuka F, Tamura I, Taniguchi K, Maekawa R, Asada H, Shimamura K, Reiter RJ, and Sugino N (2011) Protective role of melatonin in progesterone production by human luteal cells. J Pineal Res 51: 207-213.

116. Soares JM Jr, Masana MI, Ersahin C, and Dubocovich ML (2003) Functional melatonin receptors in rat ovaries at various stages of the estrous cycle. J Pharmacol Exp Ther 306: 694-702.

117. Sundaresan NR, Marcus Leo MD, Subramani J, Anish D, Sudhagar M, Ahmed KA, Saxena M, Tyagi JS, Sastry KV, and Saxena VK (2009) Expression analysis of melatonin receptor subtypes in the ovary of domestic chicken. Vet Res Commun 33: 49-56.

118. Niles LP, Wang J, Shen L, Lobb DK, and Younglai EV (1999) Melatonin receptor mRNA expression in human granulosa cells. Mol Cell Endocrinol 156: 107-110.

119. Rocha RM, Lima LF, Alves AM, Celestino JJ, Matos MH, Lima-Verde IB, Bernuci MP, Lopes CA, Bao SN, Campello CC, Rodrigues AP, and Figueiredo JR (2012) Interaction between melatonin and follicle-stimulating hormone promotes in vitro development of caprine preantral follicles. Domest Anim Endocrinol 2012 Aug 9 [Epub ahead of print].

120. Tsiligianni T, Valasi I, Cseh S, Vainas E, Faigl V, Samartzi F, Papanikolaou T, Dovolou E, and Amiridis GS (2009) Effects of melatonin treatment on follicular 
development and oocyte quality in Chios ewes - short communication. Acta Vet Hung 57: 331-335.

121. Guerin P, El Mouatassim S, and Menezo Y (2001) Oxidative stress and protection against reactive oxygen species in the pre-implantation embryo and its surroundings. Hum Reprod Update 7: 175-189.

122. Tamura H, Takasaki A, Miwa I, Taniguchi K, Maekawa R, Asada H, Taketani T, Matsuoka A, Yamagata Y, Shimamura K, Morioka H, Ishikawa H, Reiter RJ, and Sugino N (2008) Oxidative stress impairs oocyte quality and melatonin protects oocytes from free radical damage and improves fertilization rate. J Pineal Res 44: 280-287.

123. Tamura H, Takasaki A, Taketani T, Tanabe M, Kizuka F, Lee L, Tamura I, Maekawa R, Aasada H, Yamagata Y, and Sugino N (2012) The role of melatonin as an antioxidant in the follicle. J Ovarian Res 5: 5.

124. Jahnke G, Marr M, Myers C, Wilson R, Travlos G, and Price C (1999) Maternal and developmental toxicity evaluation of melatonin administered orally to pregnant Sprague-Dawley rats. Toxicol Sci 50: 271-279.

125. Ishizuka B, Kuribayashi Y, Murai K, Amemiya A, and Itoh MT (2000) The effect of melatonin on in vitro fertilization and embryo development in mice. $J$ Pineal Res 28: 48-51.

126. Rodriguez-Osorio N, Kim IJ, Wang H, Kaya A, and Memili E (2007) Melatonin increases cleavage rate of porcine preimplantation embryos in vitro. J Pineal Res 43: 283-288.

127. Shi JM, Tian XZ, Zhou GB, Wang L, Gao C, Zhu SE, Zeng SM, Tian JH, and Liu GS (2009) Melatonin exists in porcine follicular fluid and improves in vitro maturation and parthenogenetic development of porcine oocytes. J Pineal Res 47: 318-323.

128. Papis K, Poleszczuk O, Wenta-Muchalska E, and Modlinski JA (2007) Melatonin effect on bovine embryo development in vitro in relation to oxygen concentration. J Pineal Res 43: 321-326.

129. Tamura H, Nakamura Y, Korkmaz A, Manchester LC, Tan DX, Sugino N, and Reiter RJ (2009) Melatonin and the ovary: physiological and pathophysiological implications. Fertil Steril 92: 328-343.

130. Takasaki A, Tamura H, Taniguchi K, Asada H, Taketani T, Matsuoka A, Yamagata Y, Shimamura K, Morioka H, and Sugino N (2009) Luteal blood flow and luteal function. J Ovarian Res 2: 1.

131. Tamura H, Takasaki A, Taniguchi K, Matsuoka A, Shimamura K, and Sugino N (2008) Changes in bloodflow impedance of the human corpus luteum throughout the luteal phase and during early pregnancy. Fertil Steril 90: 2334-2339.

132. Sugino N, Takiguchi S, Kashida S, Karube A, Nakamura Y, and Kato H (2000) Superoxide dismutase expression in the human corpus luteum during the menstrual cycle and in early pregnancy. Mol Hum Reprod 6: 19-25.

133. Sugino N, Takiguchi S, Kashida S, Takayama H, Yamagata Y, Nakamura Y, and Kato H (1999) Suppression of intracellular superoxide dismutase activity by antisense oligonucleotides causes inhibition of progesterone production by rat luteal cells. Biol Reprod 61: 1133-1138.

134. Scarpellini F, Mastrone M, Sbracia M, and Scarpellini L (1996) Serum lipoperoxide level variations in normal and luteal phase defect cycles. Gynecol Obstet Invest 42: $28-30$.

135. Henmi H, Endo T, Kitajima Y, Manase K, Hata H, and Kudo R (2003) Effects of ascorbic acid supplementation on serum progesterone levels in patients with a luteal phase defect. Fertil Steril 80: 459-461.

136. Buscemi N, Vandermeer B, Hooton N, Pandya R, Tjosvold L, Hartling L, Vohra S, Klassen TP, and Baker G (2006) Efficacy and safety of exogenous melatonin for secondary sleep disorders and sleep disorders accompanying sleep restriction: meta-analysis. BMJ 332: 385393.

137. Carr R, Wasdell MB, Hamilton D, Weiss MD, Freeman RD, Tai J, Rietveld WJ, and Jan JE (2007) Long-term effectiveness outcome of melatonin therapy in children with treatment-resistant circadian rhythm sleep disorders. J Pineal Res 43: 351-359.

138. Chan WY, and Ng TB (1994) Development of pre-implantation mouse embryos under the influence of pineal indoles. J Neural Transm Gen Sect 96: 19-29.

139. McElhinny AS, Davis FC, and Warner CM (1996) The effect of melatonin on cleavage rate of $\mathrm{C} 57 \mathrm{BL} / 6$ and $\mathrm{CBA} / \mathrm{Ca}$ preimplantation embryos cultured in vitro. $J$ Pineal Res 21: 44-48. 